\title{
人工土壤中でのSUS304鋼のすきま腐食再不動態化電位
}

\author{
今 井八 郎*

\section{Repassivation Potential for Crevice Corrosion of SUS304 Stainless Steel in Artificial Soil}

Hachiro IMAI*

Key Words : Stainless Steel, Crevice Corrosion, Repassivation Potential, Artificial Soil

\section{1. 緒言}

ステンレス鋼は，水道用管など土壌中で用いられること も多い。それに伴い各種の実環境中での耐食試験も行わ れている ${ }^{1)}$ 。しかし，実験に長時間要するという問題 ${ }^{2}$ や本当に実環境をシュミレートしているかという問題す 常におこっている3 ${ }^{3}$ 。そのため長期を要する試験にとっ ては, 土壌中での $\mathrm{Cl}^{-}$濃度, 含水量の影響を実験室的 に調へ，腐食傾向を予測することの必要性は高い。しか し，現在までそのような研究はほとんど行われていない。 土壤と接するステンレス鋼材の腐食形態は，おむに $\mathrm{Cl}^{-}$ 濃度, 含水量によって変化し, 孔食状, すきま腐食状 に損傷する場合が多い4)。そこで本研究においては, ケ イ砂による人工土壌中でのSUS304鋼のすきま腐食性を 調べた。ステンレス鋼一砂粒界面ですきまが形成される と予想し，人工土壌中に $\mathrm{NaCl}$ 水溶液を浸透させ，その $\mathrm{Cl}^{-}$濃度, 含水量を変化させ, すきま腐食再不動態化 電位， $E_{R}$ を測定することによりSUS304鋼のすきま腐 食性を検討した。

\section{2. 実験方法}

供試材は, 市販のSUS304 - 2 B 鋼 (C : 0.064, Si : $0.55, \mathrm{Mn}: 0.97, \mathrm{P}: 0.027, \mathrm{~S}: 0.008, \mathrm{Ni}: 9.42$, $\mathrm{Cr}: 18.38, \mathrm{Mo}: 0.11, \mathrm{Cu}: 0.05, \mathrm{~N}: 0.012$, す べて wt\%）の板材を $20 \times 30 \times 2{ }^{\mathrm{t}} \mathrm{mm}$ に切断し, 所定の研 磨後 $16 \times 24 \mathrm{~mm}$ の試験面を残し, シリコン系の被覆剤でコー ティングし, 電極とした。人工土壌は, 秩父 8 号ヶイ砂 (主成分は, $\mathrm{SiO}_{2}: 93.40, \mathrm{Al}_{2} \mathrm{O}_{3}: 2.08, \mathrm{Fe}_{2} \mathrm{O}_{3}$ : 1. 59, $\mathrm{CaO}: 0.44, \mathrm{MgO}: 0.45$ すべて wt\%, 平均粒径 53-74 $\mu \mathrm{m})$ を用い前处理として土㙴中の水分を除去す るため $370^{\circ} \mathrm{C} て ゙ 1$ 時間ベーキングして，その後所定の濃 度の $\mathrm{NaCl}$ 水溶液を添加した。対極には試験電極と同材 を用いた。測定用照合電極は，セルロイド製の管とゴム

* 芝浦工業大学（テ108 東京都港区芝浦 3 - 9 -14）

Shibaura Inst. of Tech. ( $9-14$, Shibaura 3 -chome, Minato-ku, Tokyo 108 )
球で保護した飽和甘こう電極を使用した。先端を保護す るゴム球の一定部分にキャピラリーとして炉紙をとりつ けた。先端よりのCl- の溶け出しがほとんどないこと を確認の上試験に供した。乾燥土 $1 \mathrm{~kg} に 10 \mathrm{ppm} \sim 6.07$ $\times 10^{4} \mathrm{ppm} \mathrm{Cl}^{-}$に調整した $\mathrm{NaCl}$ 水溶液を $2.0 \times 10^{-2}$ $\sim 5.0 \times 10^{-1} \mathrm{dm}^{3}$ 含ませ十分かく拌し, 人工土堙とし た。すきま腐食再不動態化電位, $E_{R}$ の測定は, 辻川ら の方法 ${ }^{5)}$ に準じて行った。

\section{3．実験結果及び考察}

3. 1 すきま腐食再不動態化電位, $\boldsymbol{E}_{R}$ に及ぼす人工 土壤中の $\mathrm{Cl}^{-}$濃度の影響

$E_{R}$ を測定するためのくり返し分極曲線は, $\mathrm{Cl}^{-}$濃度 が比較的高く, 含水量屯多いと水溶液中での分極曲線と ほぼ同様であった。 $E_{R}$ 值が $0.1 \mathrm{~V}$ vS SCEより貴の時 には孔食を伴う場合むあった。しかし， $\mathrm{Cl}^{-}$濃度が低 く, 含水量が低いと肉眼で腐食が観察されず, 試験片に 流れる電流值が $20 \mu \mathrm{A}$ に達するまでに+1.0V vs SCE をはるかにこえていた。この場合は $20 \mu \mathrm{A}$ で折り返し, $E_{R}$ を測定したが測定不能のあのあ多く存在した。この 限界については，3．２項で測定後の腐食形態とともに 判定した。

くり返し分極曲線より求めた人工土壤中の $E_{R}$ 值を $\mathrm{Cl}^{-}$濃度変化によりまとめたものが図 1 である。 $\mathrm{Cl}^{-}$濃 度が高くなると $E_{R}$ 值は卑になることがわかる。また， 同図中に示す数值は土壤 $1 \mathrm{~kg}$ 中に含有する総水分量を 示す。これからもわかるように同じ $\mathrm{Cl}^{-}$濃度であ水分量 の多い場合の方が $E_{\mathrm{R}}$ 值は卑になる傾向を示す。水分量 が多くなるとC1-濃度が低いところまで $E_{\mathrm{R}}$ 測定が可能 であったが総水分量が $2.0 \times 10^{-2} \mathrm{dm}^{3}$ では $6.07 \times 10^{3} \mathrm{Cl}^{-}$ ppm以上でないと測定が不可能だった。このことより $\mathrm{Cl}^{-}$濃度とともに含水量が腐食に大きく影響しているこ とがわかる。ステンレス鋼と土壤粒子は十分充てんして あ, ある空隙が存在する。この空隙に $\mathrm{Cl}^{-}$を含む水がし み込み，ステンレス鋼表面に達し，かつ酸素が十分に届 かないと腐食が進行する。最終的にはステンレス鋼板と 


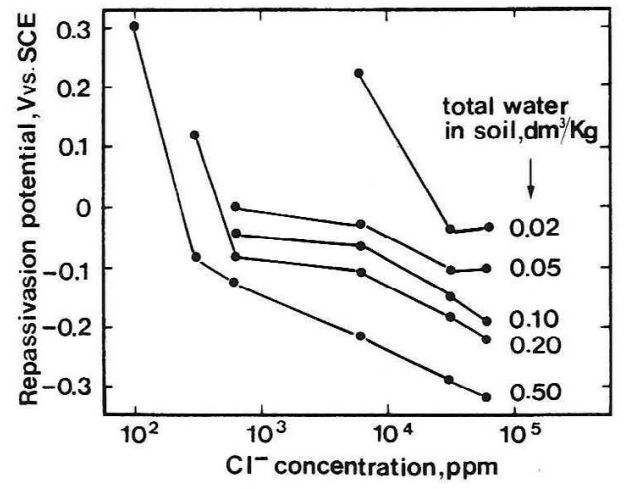

Fig. 1 Influence of $\mathrm{Cl}^{-}$concentration in soil on repassivation potential, $E_{R}$ for crevice corrosion of Type SUS304 stainless steel in artificial soil.

土㙵粒子の形状的な問題で粒子状腐食を呈する。水及び 酸素が少ないとOH-の供給が十分でないので腐食は進 行しにくい。実際の土壤では, 粒子む不揃いでしかも石, 粘土など多くの成分が混合しているものなのでさらに複 雑な腐食過程を示すと思われる。

\section{2 腐食形態について}

$E_{R}$ 測定後の試料表面を観察すると図 2 のように粒状 の腐食が観察されるあのがほとんどであった。C1-濃度 により，程度に差はあるがほぼ同様に粒状を呈した。試 験片と砂粒との間ですきま腐食が発生したものと予想さ れる。Cl-濃度が高いと粒状腐食同士が衝突して全面腐 食状を示したものが一部観察された。また，前述のよう に，非常にわずかであるが孔食す観察された。このよう な腐食の程度を $\mathrm{Cl}^{-}$濃度, 含水量によって定性的にま之 めたものが図 3 である。ほとんど腐食が観察されないむ の (○印), 腐食が軽微のもの (印), 粒状腐食が強い あの (印), 腐食が激しく全面腐食状を示すもの

印）に分類された。これからあわかるようにCl一濃度が 高くなればなるほど腐食は激しくなり, 前述の $E_{R}$ の結 果とあ一致するが含水量むかなり大きく影響している。 腐食部のSEM像を観察すると, すきま溶け出し部は浅 く，かなり広がりが見られる。侵食の深部（図 2）は, オーステナイト結晶粒界がはっきりと観察された。また, 水溶液系で観察されたような方位性エッチピットは観察 されなかった。土壌粒子一つが接するとみられるところ が強く侵食し, まわりは浅く, 粒子とステンレス鋼がす きまをつくっていたことが推測された。

\section{4. 結言}

人工土壌中でのSUS304鋼のすきま腐食再不動態化電 位， $E_{R}$ を測定した。結果を要約すると以下のようである。

(1) $E_{н}$ は，土壌中の $\mathrm{C1}^{-}$濃度が高いほど，また含 水量が多いほど卑になった。Cl-濃度が高くてあ含水量 が少ないとすきま腐食は, 発生しない。

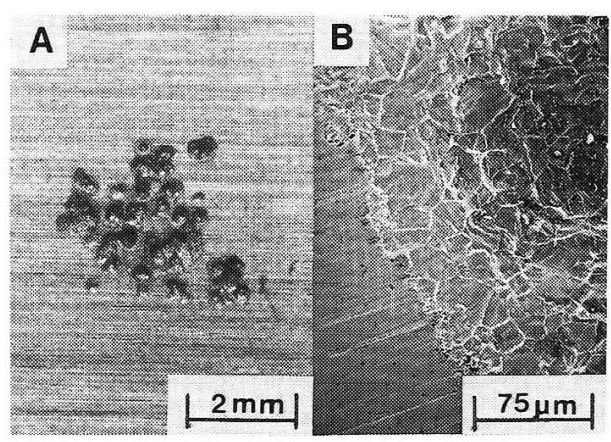

Fig. 2 Microstructures after corrosion test in artificial soil containing $3.04 \times 10^{4} \mathrm{ppm} \mathrm{Cl}^{-}$.

(A) Appearance of crevice corrosion.

(B) SEM image of well developed corrosion site with austenitic grain boundaries.

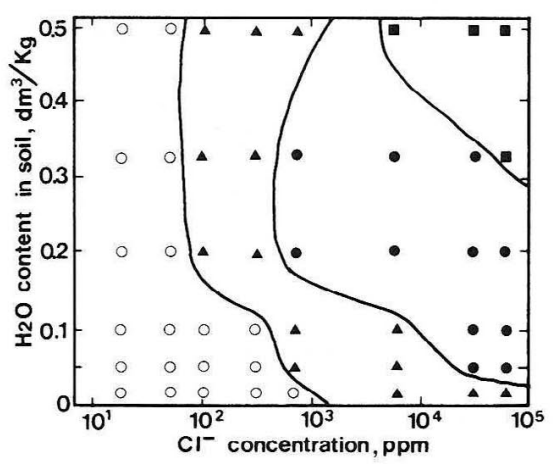

Fig. 3 A type of crevice corrosion after $E_{n}$ measurement in artificial soil.

: no corrosion

A : light crevice corrosion

- crevice corrosion with granular attacks as Fig. 2 (A).

: general corrosion with deep penetration.

(2) $E_{R}$ 測定後の腐食の形態は，粒子状のすきま腐 食的様相を呈している。 $E_{R}$ が $0.1 \mathrm{~V}$ VS SCEより貴に なる条件では孔食す観察された。

（3） $\mathrm{Cl}^{-}$濃度と含水量の図より腐食限界を判定する 上, $\mathrm{Cl}^{-}$濃度が50 ppm以下になると含水量が多くても 腐食は発生しない。含水量が $2.0 \times 10^{-1} \mathrm{dm}^{3}$ 以上にな ると, $100 \mathrm{ppm} \mathrm{C1}$ 以上では含水量に関係なくすべて腐 食が発生する。

(1988-9-10 受理)

\section{文献}

1) 遅沢浩一郎, 堀岡勝彦, 小林末子夫, 木谷 滋, 沢村栄男, 井上裕夫 : 鉄上鋼, 68, S 1492 (1982)

2) 小林末子夫, 木谷 滋, 遅沢浩一郎, 堀岡勝彦, 沢村栄男, 井上裕夫 : 鉄と鋼, 68, S 1491 (1982)

3) 梶川 修, 佐古光聡, 高江 勉, 林 良隆, 斉藤道雄 : 材 料, 31, 1031 (1982)

4 ) 井上裕夫, 木谷 滋, 藤原最仁: 第 48 回腐食防食分科会資 料, p. 84 (1981)

5 ）辻川茂男, 久松敬弘 : 防食技術，29，37（1980） 